\title{
U4/U6.U5 Tri-SnRNP-Associated Protein 1
}

National Cancer Institute

\section{Source}

National Cancer Institute. U4IU6.U5 Tri-SnRNP-Associated Protein 1. NCI Thesaurus. Code C129083.

U4/U6.U5 tri-snRNP-associated protein 1 ( $800 \mathrm{aa}, \sim 90 \mathrm{kDa}$ ) is encoded by the human SART 1 gene. This protein is involved in RNA splicing. 